\title{
Book review: \\ Boyle, J.M. (Eds.). (2019). Non-Western Responses to Terrorism. Manchester: Manchester University Press, 504 p.
}

\author{
B. Mugabi \\ RUDN University, Moscow, Russian Federation
}

For citation: Mugabi, B. (2020). Book review: Boyle, J.M. (Eds.). (2019). Non-Western Responses to Terrorism. Manchester: Manchester University Press, 504 p. Vestnik RUDN. International Relations, 20 (4), 836-838. DOI: $10.22363 / 2313-0660-2020-20-4-836-838$

\section{Рецензия на книгу: \\ Non-Western Responses to Terrorism / Ed. by J.M. Boyle. Manchester: Manchester University Press, 2019. 504 p.}

\author{
Б. Мугаби \\ Российский университет дружбы народов, Москва, Российская Федерация
}

Для цитирования: Mugabi B. Book review: Non-Western Responses to Terrorism / Ed. by J.M. Boyle. Manchester: Manchester University Press, 2019. 504 p. // Вестник Российского университета дружбы народов. Серия: Международные отношения. 2020. Т. 20. № 4. С. 836-838. DOI: 10.22363/2313-0660-2020-20-4836-838

The book under review, as expounded upon by M.J. Boyle [2019], narrates the differences and similarities of counter-terrorism approaches of Non-Western countries according to a regional basis with different special case studies developed by the authors. Researchers turned to historical narratives and discovered new counterterrorism approaches that are restricted to those given societies instead of the general western counter-terrorism approach after the 11 September 2001 attack on the United States.

According to the authors, Ekaterina Stepanova, Irene Chan, Rashmi Singh, Jorge M. Lasmar, and Emma Leonard Boyle, account that the conceptualization of terrorism shapes how states respond to the emergence of the war on terror in their respective societies. Some governments in the Middle East and North
Africa reject the American portrayal of terrorism as an intractable ideology since, according to them, such tantamount to islamophobia.

On the contrary Western counter-terrorism approaches, mainly referring to North America and Europe, have received a wide range of publications and discourse often underlooking the Non-Western counter-terrorism approaches.

A different narrative from Non-Western societies seems to be the guiding principle for the authors' comprehensive accounts of the various counter-terrorism policies across the non-western world. The book's central argument is that Non-Western counter-terrorism policies are in varying degrees influenced and mediated by factors such as:

(C) Mugabi B., 2020

This work is licensed under a Creative Commons Attribution 4.0 International License.

https://creativecommons.org/licenses/by/4.0/ 
1) Historical experience of war, occupation, and colonialism;

2) Local politics and the distribution of power among domestic stakeholders;

3) International religious divisions or debates within key sectarian communities;

4) Cultural traditions and experiences.

The book's narrative under review looks very logical and persuasive.

Part I Russia and Central Asia. This part is devoted to portraying how Russia's conceptualization of terrorism has a significant effect on its counter-terrorism policy. The author notes that Russia's exclusion in its definition of terror uses force by insurgent military actors against military targets and violence by the state itself against its civilians, which predates the 2011 consensus definition of terrorism. Therefore, the Russian perspective on terrorism is described, based on the reading of the state's threat and general functionality given its social diversity. The author's heed to the narrative that Russia's conception of terrorism has gradually expanded from focusing on the North Caucasus' wars to fighting against the ISIS $^{1}$ insurgency. Thus, Russia's counter-terrorism strategy is a conglomerate of counterinsurgency and containment of Islamist forces and others perceived to threaten the state's security.

Part II Asia. In the China case, the author demonstrates a convenient correlation between terrorism and separatist movements in ethnic autonomous regions, distinctively the Xinjiang Uyghur autonomous region. Through legislation, China has built a corpus of law designed to identify and criminalize subversive actions that may inspire dissent or terrorism. Consequently, China amalgamated the three evils: terrorism, separatism, and religious extremism as those to be countered by the State.

The counter-terrorism policy of Malaysia is synonymous with the British colonial legacy in the 1950s. As a result, a counter-terrorism measure considers pre-emptive legal measures, and therefore arrests are warranted against those suspected of extremism ${ }^{2}$.

\footnotetext{
${ }^{1}$ This organization is forbidden in the Russian Federation.

2 A paper on terrorist threat in South-East Asia was published at Vestnik RUDN. International Relations [Rogozhina 2017] (Editors' note).
}

Part III South Asia. The book illustrates how tensions emanating from ethnicity, caste, religion, and social-economic concerns propel India's counter-terrorism approach. Thus, such indicators in India lead to a threat of hybrid cases of insurgency and terrorism, subjectively distinguished, which, according to the author, leads to a contradictory counter-terrorism policy.

Pakistan's historical founding as a state, the author, argues that it correlates with its counterterrorism approaches ${ }^{3}$. Its break away from India and the fight over Kashmir combined with the state's oppression of minority groups remains one of the underlying factors that promote the rise of terrorism.

Part IV Latin and South America. The author asserts that Brazil is more threatened by political violence than terrorism, which can be justified by its foreign policy that is regarded as a pacifist and, therefore, unwilling to engage non-violent state actors. On the contrary, the book illustrates how the United States largely influences Colombia's counter-terrorism approach with a difference in application. Terms such as narcoterrorism are applied in a counterterrorism approach and fighting against paramilitary groups, guerillas, and others.

Part V The Middle East and North Africa. In this part, the book's striking similarities of four state case studies portray these states as actors that use repression to meet their desired objectives. In the Algerian case, violent extremism is traced from colonial times during its revolutionary struggle for self-determination; however, the same traits remain prevalent, given the violent non-state actors within its peripheries. The author notes that the Saudi conception of terrorism assumes that Wahhabi Islam and terrorism are mutually exclusive ${ }^{4}$. Needless to say is that Saudi Arabia conceives of extremism and deviation from accepted religious practice in individual and personal terms, apart from the government. Hizballah, too offers its interpretation of terrorism within Lebanese politics.

\footnotetext{
${ }^{3}$ Previously, at Vestnik RUDN. International Relations a paper on the counter-terrorism approach of Pakistan was published [Malik, He, Rafay 2019] (Editors' note).

${ }^{4}$ Paper on internal origins of terrorism in Saudi Arabia was published at Vestnik RUDN. International Relations by leading Russian scholar G. Kosach [2017] (Editors' note).
} 
Part VI Africa. The book indicates the African counter-terrorism approach, which is mostly a reflection of the western counterterrorism approach due to different factors, including but not limited to the colonial legacy. Adopting the Western approaches that do not reflect local realities has left Kenya with aggravated communal divisions and tensions, demonstrating incoherence within its counterterrorism policy ${ }^{5}$.

In Nigeria, terrorism posed by Boko Haram compelled the state to device more regressive measures that have affected its social and economic base, hence directly affecting the civilians who should be protected through an adequately drafted counter-terrorism policy that is directly targeted at the terrorist group ${ }^{6}$.

5 Analysis of terrorist challenges in Kenya was provided in a paper published at Vestnik. RUDN. International Relations [Morumbasi, Amuhaya 2016] (Editors' note).

${ }^{6}$ A series of papers on fighting Boko Haram in Nigeria and in Cameroon was previously published at Vestnik
Finally, in Uganda, the author portrays Uganda's long struggle with terror first within her borders, as demonstrated by its fight against LRA. The author narrows Uganda's commitment to regional security to the president's bid in boosting his regional ambition. This narrative undermines regional efforts in counter-terrorism, primarily through AMISOM and IGAD, whose cooperation and coordination have played a significant role contrary to the authors' assertion of sole players.

Conclusively, it is imperative to note that there is little difference between Western and Non-Western approaches to counter-terrorism at closer inspection. The practices of some NonWestern governments are deeply influenced by western practice with differences in interpretation and implementation.

RUDN. International Relations [Bakare 2016; Bokeriya, Omo-Ogbebor 2016; Kouma 2017] (Editors' note).

Received / Поступила в редакцию: 25.09.2020 Accepted / Принята к публикации: 08.10.2020

\section{References / Библиографический список}

Bakare, I.A. (2016). Soft Power as a Means of Fighting International Terrorism: A Case Study of Nigeria's "Boko Haram". Vestnik RUDN. International Relations, 16 (02), 285-295.

Bokeriya, S.A. \& Omo-Ogbebor, O.D. (2016). Boko Haram: A New Paradigm to West Africa Security Challenges. Vestnik RUDN. International Relations, 16 (02), 274-284.

Boyle, J.M. (Eds.). (2019). Non-Western Responses to Terrorism. Manchester: Manchester University Press.

Kosach, G.G. (2017). Saudi Arabia: Interior Origins of Terrorism. Vestnik RUDN. International Relations, 17 (04), 639-654. (In Russian). DOI: 10.22363/2313-0660-2017-17-4-639-654

Kouma, J.G. (2017). Cameroon Fighting Boko Haram. Vestnik RUDN. International Relations, 17 (04), $727-737$. DOI: $10.22363 / 2313-0660-2017-17-4-727-737$

Malik, Z.U., He, Z. \& Rafay, M. (2019). War on Terrorism in Pakistan: Challenges and Strategic Steps. Vestnik RUDN. International Relations, 19 (04), 625-631. DOI: 10.22363/2313-0660-2019-19-4-625-631

Morumbasi, S.K. \& Amuhaya, C. (2016). A Networks Analysis of Terrorism in Africa: Implications for Kenya. Vestnik RUDN. International Relations, 16 (02), 265-273.

Rogozhina, N.G. (2017). The Threat of Terrorism in South-East Asia. Vestnik RUDN. International Relations, 17 (04), 697-709. (In Russian). DOI: 10.22363/2313-0660-2017-17-4-697-709

About the author: Mugabi Brian - Assistant, Department of Theory and History of International Relations, RUDN University (e-mail: mugabi-b@rudn.ru).

Сведения об авторе: Мугаби Брайан - ассистент кафедры теории и истории международных отношений Российского университета дружбы народов (e-mail: mugabi-b@rudn.ru). 